\title{
Perception of Educators towards the Adoption of Education 5.0: A Case of a State University in Zimbabwe
}

\author{
${ }^{1}$ Dumisani Rumbidzai Muzira, PhD, ${ }^{*}$ and ${ }^{2}$ Beatrice Maupa Bondai \\ ${ }^{1}$ Marondera University of Agricultural Sciences and Technology, Zimbabwe \\ ${ }^{2}$ University of Zimbabwe \\ ${ }^{*}$ Corresponding author: $\underline{r d m u z i r a @ m u a s t . a c . z w}$
}

\begin{abstract}
This study was an exploration of educators' perceptions towards the adoption of Education 5.0 which was conducted at a state University in Zimbabwe. Education 5.0 is a new curriculum reform that would need a buy-in of educators for possible smooth implementation. The study revealed that educators perceived Education 5.0 as a helpful and more beneficial to the education system than the preceding Education 3.0 although they bemoaned lack of infrastructure and financial resources for proper implementation. The study recommended that the University administrators should source funding from business partners and banks to build physical infrastructures such as industrial parks and innovation hubs to support Education 5.0 adoption. The study also recommended that the Ministry of Higher and Tertiary Education, Innovation, Science and Technology Development conduct seminars with educators to address sticky issues regarding Education 5.0, since educators are directly involved in its implementation.
\end{abstract}

Key words: Educators, Education 3.0, Education 5.0, Curriculum reform

\section{Introduction}

This study sought to explore perceptions of educators in a state University towards the adoption of Education 5.0 which is a curriculum change that is at its implementation stage in Zimbabwean universities. Brief explanations on reforms of the Zimbabwean education system during pre-colonial, colonial and post-colonial eras and also the steps to achieve Education 5.0 are presented. The level of preparedness of the implementers and the implementing organization have an influence on the success or failure of the change reform (Hayes, 2010), hence the need to explore perceptions of educators towards implementation of Education 5.0.

Zimbabwe experienced some reforms in its education system which can be categorized as precolonial, colonial and post-colonial education (Zvobgo, 1986; Mapara, 2009). The post-colonial can be further divided into two; Education 3.0 and Education 5.0. Education 3.0 is the tertiary education that focuses on three pillars namely research, teaching and community service while education 5.0 focuses on five pillars which are research, teaching, community service, innovation and industrialization (Ministry of Higher and Tertiary Education, Science and Technology Development (2018a). The curriculum shifts from preparing students for white collar and blue collar jobs to preparing them for job creation by using generated knowledge for the creation of goods and services. For a successful implementation of any change initiative, certain implementation steps should be followed (Jabri, 2012; Harpe, \& Thomas, 2009). Since Education 5.0 is a curriculum reform, buy-in from the curriculum implementers is essential to reduce the chances of change resistance (Kotter, 1995; Armenakis, Harris, \& Mossholder, 1993).

Change studies have generally shown that high readiness results in change success while low readiness usually results in change failure (Kotter, 1995). High readiness means that all the necessary 
resources and infrastructure to support the change are in place and both management and employees are well prepared for the change while low readiness would mean scoring lowly on these aspects. In addition, readiness generally reduces the chances of change resistance (Armenakis, Harris, \& Mossholder, 1993). This therefore suggests that a buy in from those who are to implement Education 5.0 is necessary for its success. Resistance would lead to poor implementation of the program, full implementation taking longer than expected resulting in wastage of time and resources and also frustration among the implementers. Studying readiness for adoption was therefore a proactive approach of managing this eminent change in education. Educators being the implementers of curriculum change, it then became necessary to explore their perceptions towards the adoption of Education 5.0 and to assess their readiness for adoption level.

Imparting life skills has been central to most of the education reforms in Zimbabwe. During the precolonial era, the youths were taught farming, hunting, iron smelting and household chores (Mapara, 2009). In the colonial era the same skills were being taught using advanced equipment combined with academic subjects. However, there was racial segregation in the allocation of resources including teaching materials and equipment (Sarup, 2013). The post-colonial era made university education accessible to most students with the introduction of private universities and more state universities (Kanyongo, 2005). However, this brought an influx of academically sharp graduates who needed to be employed and the job market was flooded. In order to address this and other developmental challenges in Zimbabwe, Education 5.0 which is heritage based, seeking to cultivate students' entrepreneurial skills for the development of industries was introduced. This was done with the hope of creating new jobs, reducing unemployment, earning foreign currency for the country by exporting the produced goods and services and also helping to solve some societal deviant behaviors often associated with poverty and unemployment such as, stealing, armed robberies and drug abuse.

Adoption could be influenced by the university's interior factors such as physical infrastructure, financial resources, employees' attitude towards organizational change, their perceived usefulness of the change, innovation characteristics such as relative advantage, complexity of the innovation (Aarons, Hurlburt, \& Horwitz, 2011; Davis, 1989; Rogers, 2003) and/or exterior factors such as political, economic, social, technological, environmental, and legal (Kotler, 2012). This study only concentrated on the university's interior factors since organizations have more control on interior than exterior factors. A case study of one university limited generalizability of the study results.

\section{Related Literature and Studies}

This part presents literature review and studies that relate to the problem under investigation.

\section{Education Reforms in Zimbabwe}

Zimbabwe has experienced some reforms in its education system which can be categorized as precolonial, colonial and post-colonial education. The post-colonial can be further divided into two; Education 3.0 and Education 5.0. The shift from Education 3.0 to Education 5.0 was necessitated by the need to prepare university students for job creation and not to be jobseekers. This would then help to ease the unemployment situation in the country. In order for any change initiative to succeed, there are certain implementation steps to be followed to manage the change reform (Armstrong, 2003). Below are the brief descriptions of the education reforms and the steps to be followed to achieve Education 5.0.

\section{Pre-Colonial education}

The pre-colonial education which is called traditional knowledge, indigenous knowledge or ethno-science by some authors was more of the informal education offered by elders to the young (Nyota and Mapara, 2008). This type of education focused on grooming girls to be good wives and mothers. The girls were taught how to do the household chores and how to care for the children. The boys were groomed to be responsible men who would be able to provide for their families. They would be taught life skills such as farming, hunting, carpentry and iron smelting. The pre-colonial education used semi-skilled tools such as bows and arrows for hunting and hoes for farming (Needham, 1974). These tools were later improved in the colonial era by the introduction of machinery such as tractors for farming and guns for hunting. Traditional knowledge was also used for weather forecasting, security and also for medicine. This then led to the recognition of traditional healers through 
Zimbabwe National Traditional Healers Association (ZINATHA) in 1980 (Mapara, 2009).

\section{Colonial Education}

Colonial education promoted white racial superiority over non-white people to such an extent that the colonizers' language, customs and culture were considered superior (Mapara, 2009). Missionaries through the establishment of mission schools were the ones who provided formal education to Zimbabwe's indigenous people (Kanyongo, 2005). As a result, missionary schools such as Gokomere, Nyazura and Solusi were established. The colonial administrators, however, controlled the curriculum that was to be taught in these mission schools (Shizha \& Kariwo, 2011). The indigenous people were educated to be laborers for the Europeans (Dorsey, 1975 in Kanyongo, 2005). The indigenous people's education included mainly practical subjects such as agriculture, building, carpentry and dress making. There was racial inequality as the Europeans went to group $A$ schools while the indigenous people went to group $B$ schools (Kanyongo, 2005). Group A were high-fee paying schools that were meant for white students only and were well resourced in terms of teaching materials while group B schools were low-fee paying schools meant for the Africans, located in urban African residential areas where the infrastructure was sub-standard (Shizha \& Kariwo, 2011).

In the same era, skills such as dressmaking, carpentry and building were taught but racial inequality existed. The group A schools had better equipment to use than group $B$ schools. English was the official language of communication in the education system and was also a pre-requisite for most colleges and university entry (Kadenge \& Nkomo, 2011; Shizha \& Kariwo, 2011). The Marxist perspective was very visible during the colonial education system as those in charge of the means of production could afford to put their children to expensive schools which could offer quality education using good teaching materials but those with the indigenous background could not afford these good schools (Sarup, 2013). The cheap schools would offer poor education using minimum resources. Very few blacks could make it to university since there was only one university by that time, which is the University of Zimbabwe. This meant that many blacks were left out to be absorbed by vocational colleges, teachers' colleges and nursing colleges.

\section{Post-colonial Education}

After independence in 1980, the government sought to reverse the racial and gender inequalities in education (Gordon, 1994). Education was made accessible to all, thereby promoting gender and racial equity in education (Kanyongo, 2005). In order to address this, many schools were opened in the rural areas, primary education was made compulsory, hot seating was introduced, and temporary teachers were recruited to help meet demand for teachers. Vocational schools were there to impart life skills but were resented by the blacks as they viewed them to be a form of colonization (Zvobgo, 1986). Practical subjects were taken to be of lesser value than academic subjects. The introduction of Technical Colleges somehow eased this tension since it introduced some mechanical and electrical engineering courses over and above the usual dressmaking, carpentry and building courses. Dressmaking was also changed to clothing and textiles which incorporated other related skills over and above sewing. Competition to university education was stiff as there was one university nationwide which could only absorb a small fraction of the students from high schools.

In order to address the demand for university education, private universities such as Solusi University and Catholic University were given university charters. This led to an increased number of graduates to such an extent that these graduates could not be absorbed by the industry. This large influx of graduates then led to increased unemployment rates and the graduates lacked the skills required by employers (Kanyongo, 2005). Industrial attachment was then introduced so that students are given a chance to practice what they would have learnt in class. The government revisited the curriculum offered in primary, secondary and tertiary education. Education with production was introduced in primary schools and non-formal education and technical education were introduced to school leavers (Zvobgo, 1986). Correspondence education and adult literacy were also promoted by the Ministry of Education under the department of non-formal education (Zvobgo, 1986). The National Manpower Survey (NMS) done in 1981 revealed that the majority of the Africans were occupying the lower skill jobs hence the introduction of technical colleges to bridge this gap (Zvobgo, 1986). Higher education was not spared of these reforms and therefore the next discussion is on higher education reforms from Education 3.0 to Education 5.0. 


\section{Education 3.0}

New courses in areas such as Food Science, Child Health, Veterinary Sciences and Urban planning were introduced soon after Zimbabwe's independence because of their relevance to a developing country (Zvobgo, 1986). Zvobgo (1986) goes on to say, "universities must, through research, open new possibilities for national development in various spheres and must participate vigorously in community and national programs of development ..." (p.133). Industry, society, and the nation at large, therefore, looked up to universities to provide solutions to the country's developmental needs. This background could have informed Education 3.0 which had only three pillars; research, teaching and community service. As a result, universities were to focus on research since most innovation is informed through it. Teachers had a link with the quality of graduates produced by an institution (Blazar \& Kraft, 2017); hence teaching is of paramount importance to universities. Community service is also important to universities since these institutions are sustained by resources provided by the people.

Therefore, universities need to plough back to the community by utilizing attained knowledge to alleviate the multi-faceted problems prevalent in their societies (Nyerere in Zvobgo, 1986). However, Education 3.0 did not yield the expected results of developing industries as there was a disconnect between knowledge gained in Higher and Tertiary Education system and the local environment as the Higher and Tertiary Education system seemed to be concentrating on exotic application domains (Murwira, 2019). Another reform of the education system became necessary hence the introduction of Education 5.0.

\section{Education $\mathbf{5 . 0}$}

Education 5.0 was introduced as an attempt to match Zimbabwean curriculum to Zimbabwean culture as well as the country's developmental needs. The Heritage based philosophy which is being promoted by the current Minister of Higher and Tertiary Education, Professor A. Murwira supports the application of gained knowledge on the local environment in order to produce relevant goods and services (Ministry of Higher and Tertiary Education, Science and Technology Development, 2018a). Two pillars were then added to those in Education 3.0. Hence Education 5.0's focus is on research, teaching, community service, innovation and industrialization (Ministry of Higher and Tertiary
Education, Science and Technology Development, 2018a). The teaching aspect now requires that theory be blended with practice in teaching. As a result, the Minimum Bodies of Knowledge and Skills $(\mathrm{MBK} / \mathrm{S})$ that are being introduced to the university curriculum will also influence teaching. These require similar programs in different Zimbabwean institutions of higher education to teach $80 \%$ of similar content and the difference should be only $20 \%$ (MBK/S strategic plan document). This would harmonize the higher education sector in Zimbabwe, thereby allowing easy transfer of students from one institution to the other within the country. There is a deliberate link between the pillars of higher education as teaching should probe research, research influence community service through innovation, and innovation should lead to commercialization and industrialization through the introduction of innovation hubs and industrial parks (Ministry of Higher and Tertiary Education, Science and Technology Development, 2018a). Institutions of higher education would therefore produce graduates who have entrepreneurial skills and are equipped to set up industries rather than being job seekers.

This has been evidenced by Chinhoyi University of Technology's artificial insemination project launched as a way of implementing Education 5.0 (Ministry of Higher and Tertiary Education, Science and Technology Development, 2018b). Heritage based education is meant to use Zimbabwe's readily available agricultural, climatological and mineral heritage for national development (Tirivangana, 2019). Thus, more foreign currency can be earned through exportation of the produced goods and services. This would also result in job creation that would lead to lowering of unemployment rates. Education should help solve the existing societal and national problems; hence, it becomes apparent that the country's Higher and Tertiary Education system have to be transformed to meet the current developmental needs of the country (Ministry of Higher and Tertiary Education, Science and Technology Development, 2018c). As a result, the Ministry of Higher and Tertiary Education have set some steps to achieve Education 5.0 and these are briefly described below.

\section{The steps to achieve education $\mathbf{5 . 0}$}

Generally, program implementation requires clear laid down procedures to be followed by the program implementers (Jabri, 2012). The Ministry of 
Higher and Tertiary Education has suggested four steps to be followed if Education 5.0 is to succeed. These include program infrastructure, promotion infrastructure, physical infrastructure and financing infrastructure as explained below.

\section{Program Infrastructure}

The first step to implementation is to put in place the desired program. This could be done by consultations among the stakeholders which might include; curriculum specialists, teachers, students and representatives from the industry (Ornstein \& Hunkins, 2013). In Zimbabwe, Zimbabwe Council for Higher Education (ZIMCHE) has been mandated by the Ministry of Higher and Tertiary Education to implement the Zimbabwe National Qualifications Framework through Statutory Instruments: (SI 132, SI 133, SI 137 and SI 140 of 2018) to increase transparency in the country's education (Ministry of Higher and Tertiary Education, Science and Technology Development, 2018a, p. 7). Programs that are relevant to the country's developmental needs are to be offered and irrelevant programs must be scratched off. Entrepreneurship, foreign languages and computers are courses that should be offered across all degrees offered by an institution. Furthermore, degree programs should be benchmarked against reputable universities both locally and globally.

\section{Promotion infrastructure}

Promotion of lecturers should be uniform across staff in Higher and Tertiary Education institutions in Zimbabwe. The academic promotion grades are from junior lecturer to lecturer, to senior lecturer, to associate professor, and finally professor (Ministry of Higher and Tertiary Education, Science and Technology Development, 2018a). Setting criteria for promotion would help curb favoritism and promotes fair rewards to workers there by enhancing job satisfaction (Naqvi, Malik, \& Mahmood, 2013). Fairness in promotion procedures would therefore aid in equitably rewarding those who have excelled in their academic/professional ladder.

\section{Physical Infrastructure}

Physical infrastructures are capital investments which require huge financial input (Jones, Sutcliffe, Bragg \& Harris, 2016). The government alone cannot manage to finance the construction of innovation hubs, university towns and cities and make provisions for aid from other partners. The Doctrine for the Modernization and Industrialization of
Zimbabwe through Education, Science and Technology Development to achieve Vision 2030 states that Public, Private Partnerships (PPPs) are to be formed by engaging investors with the capacity to develop state of the art infrastructure for Higher and Tertiary Education institutions. These are expected to form Build Operate and Transfer (BOT), and Build Own Operate and Transfer (BOOT) arrangements with the institutions of Higher and Tertiary Education. University towns and cities are also to be established by the government as a way of providing conducive learning and nurturing environment for the students.

\section{Financing Infrastructure}

Pedagogical needs of lecturers and students such as interactive boards, projectors, computers and internet availability need funding (Jones, Sutcliffe, Bragg, \& Harris, 2016). These funds generally come from tuition fees paid by the students. A provision for student loans for payment of tuition is being made by the government through the Higher and Tertiary Educational Loan Support Facility (Ministry of Higher and Tertiary Education, Science and Technology Development, 2018a). This will lighten the student/parent or guardian burden on payments of fees. Both local and international financial institutions need to be involved in offering this facility.

\section{Conceptual Framework}

When implementing a change, it is dangerous for the implementers to presume that once an innovation has been introduced, the intended users will put the innovation into practice (Knoll, 1987, in Armstrong, 2003). There are some push and pull factors that might lead to change resistance. Individual factors, organizational factors and innovation characteristics are some of the factors to be considered when adopting a change (Muzira, 2018). Although these factors were used to determine the factors affecting readiness for integrated reporting adoption, they are also relevant for study since Education 5.0 is also a change adoption. These factors are briefly described below.

\section{Individual Factors}

The people factor is to be managed well when implementing change (Jabri, 2012). The expectancy theory developed by Vroom (1964) stipulates that expectations that individuals have towards the change and how they are met/not met has an influence on their attitude towards the adoption of 
the change. Since people have an impact on the outcome of a change, their attitude towards the change matters. The teachers' perceptions towards the adoption of Education 5.0 are therefore worth exploring. If the need for the change is communicated to employees together with the benefits of the change, employees are likely to support the change (Jabri, 2012). The attitude of the educators towards Education 5.0 should give an indication of the support or resistance the change would get. Employees are said to be willing to change if they perceive the change to be of benefit to them and to the organization (Davis, 1989; Karp \& Fletcher, 2014).

\section{Availability of Resources}

Among other factors such as organizational culture and organizational structure, availability of resources is important when implementing changes (Karp \& Fletcher, 2014; Solomons \& Spross, 2011). Generally, availability of resources has a positive influence on readiness for adoption (Aarons, Hurlburt, \& Horwitz, 2011). If the needed resources for adoption are not made available, implementation becomes a problem. In this study, the infrastructural and financial resources are the ones the researcher concentrated on since they are listed among the steps set by the Ministry of Higher and Tertiary Education to achieve Education 5.0.

\section{Innovation Characteristics}

The characteristics of the change itself have an influence on its adoption. The quality, worth, clarity, easiness, and practicality of the change is necessary for the change to be accepted (Ornstein \& Hunkins, 2013). Rogers and Shoemaker (1971, p. 154) have five innovation characteristics that are said to influence adoption and these are; observability, relative advantage, compatibility, trialability and simplicity/complexity. This study looked at relative advantage and simplicity as the characteristics that are most likely going to influence adoption of Education 5.0. Relative advantage looked into the benefits of Education 5.0 in comparison to Education 3.0. Simplicity refers to "the degree to which an innovation (Education 5.0) is perceived as relatively easy to understand and use" (Rogers \& Shoemaker, 1971, p. 154). A diagrammatic presentation of all these factors that were used to explore the educators' perceptions towards the adoption of Education 5.0 is presented in figure 1.

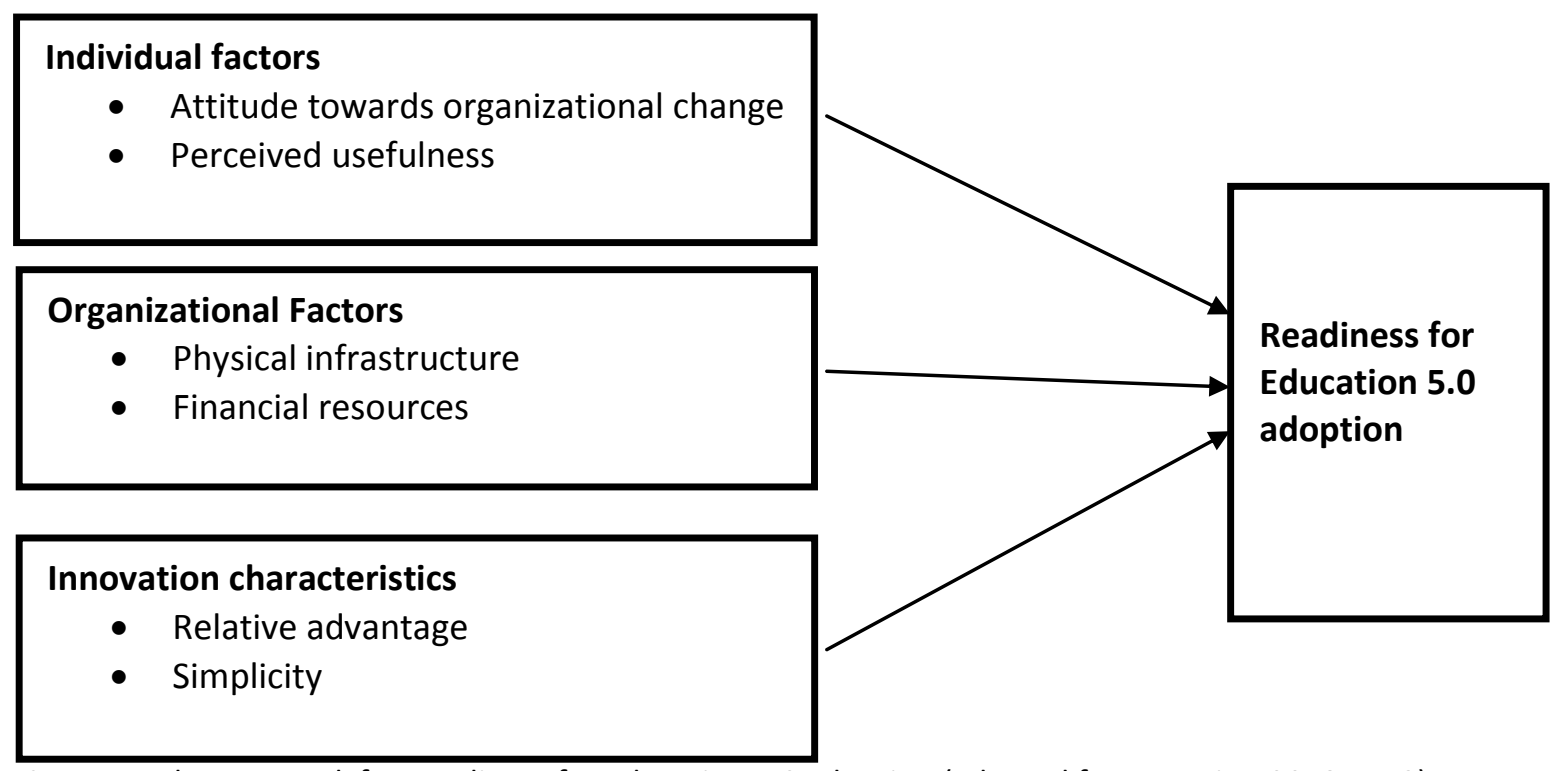

Figure 1: Conceptual Framework for Readiness for Education 5.0 adoption (adapted from Muzira, 2018, p.79).

\section{Research Methodology}

This part highlights on the methodology that guided the study.

\section{Research Design}

This study adopted Saunders, Lewis, and Thornhill (2008)'s research onion design, which moves from the outer layer to the inner layers just like an onion.
These layers are research philosophy, approach, strategy, choice, time horizon up to techniques and procedures (Saunders at el., 2008, p. 138). Interpretivism research philosophy assumes that people interpret and make their own meaning of events and that interpretation is subjective, hence there are multiple perspectives on one event (Mack, 2010). Interpretivism was then chosen as the 
research philosophy because of the nature of the study's research questions which sought to measure perceptions which are subjective and have multiple realities. An inductive approach, which involves moving from the particular to the general, was chosen for this study (Woiceshyn \& Daellenbach, 2018). The choice was influenced by the small sample size, the nature of the study which sought perceptions of educators, and the study's limited generalizability since it is case study. An inductive approach which is explained as reasoning from narrow to broad was also chosen because no theory was being developed, hypothesized or tested (Saunders at el, 2008).

\section{Population and Sampling Procedures}

The study population composed of thirty lecturers and top five administrators (Vice chancellor, registrar, dean of studies, Bursar, and librarian) from a state university, making a total of thirty-five educators. However, four lecturers were excluded from the study since they fall under the same department with one of the researchers in order to maintain objectivity.

\section{Data Collection Methods}

A survey using questionnaires was used for data collection. The questionnaire items were adapted from Muzira (2018) readiness for adoption model. The questionnaire had demographic characteristics of educators and the study variables on Readiness for Education 5.0 adoption. Each of the variables was measured using three items. The mean scores for each variable was used for measuring perceptions and determining readiness for adoption levels.

\section{Method of Data Presentation and Analysis}

The score sheet was filled in by the researcher using coded data from the responses from the questionnaires. Frequencies were used to determine the number of educators in each of the demographic sections. Data pertaining the study variables for Readiness for Education 5.0 adoption was coded using Likert scales of 1 to 5 . Items 1 to 3 were reverse coded to allow easy analysis of data by having all the responses positively framed. This meant that a response of 1 was recorded as a $5 ; 2$ as 4; 3 remained 3 because it is neutral; 4 as 2; and 5 as 1 . Averages for each variable were used to determine the perceptions of educators towards the adoption of Education 5.0. Criteria for mean score interpretation was as follows: $1.00-1.49=$ not ready for Education 5.0 adoption, 1.50-2.49=somewhat not ready for Education 5.0 adoption, 2.50-3.49= not sure if ready for Education 5.0 adoption, 3.50$4.49=$ somewhat ready for Education 5.0 adoption and $4.50-5.00=$ ready for Education 5.0 adoption.

The demographics part was analysed using frequencies and percentages. The other six variables were analyzed by calculating the mean scores for each variable. The following is description of items that were used to measure each variable:

- Attitude towards the adoption of Education 5.0 was measured by items 1,2 , and 3 .

- Perceived usefulness of Education 5.0 was measured by items 4,5 , and 6 .

- Availability of physical infrastructure to support Education 5.0 was measured by items 7, 8, and 9 .

- Availability of financial resources to support Education 5.0 was measured by items 10 , 11 , and 12.

- Relative advantage of Education 5.0 in comparison with Education 3.0 was measured by items 13, 14, and 15 .

- Simplicity of Education 5.0 was measured by items 16, 17, and 18.

\section{Ethical Considerations}

The ethical considerations that have to do with the use of questionnaires in research were observed. All the respondents were above 18 years of age, hence their signing of the informed consent form meant that they were voluntarily agreeing to participate in the study after reading the form. Permission to carry out the study was sought and granted by the Ministry of Higher and Tertiary Education and the University under study after which the questionnaires were then distributed for data collection. To maintain anonymity, the participant names and other personally-identifiable information were not indicated by respondents in the process of filling the questionnaire. To maintain academic integrity, other people's works are acknowledged by referencing all citations to avoid plagiarism.

\section{Findings and Discussion}

This part presents findings of the study based on the analysis of data.

\section{Demographic Profile of Respondents}

There were 20 males (65\%) and 11 females (35\%). This shows that there is gender imbalance of educators at the university. Age was distributed as follows; 25-40 years' category had 20 (65\%); 41-55 
years' category had 10 (32\%) while 56 years and above had 1 (3\%). This shows that there are more young educators at the university than old aged ones.

Education level was distributed as follows; masters' level 18 (66.7\%) and doctorate level 9 (33.3\%). Since more than half of the educators had a masters' degree and more than a third had a doctoral degree, this indicates that the educators at the university are qualified people since the minimum qualification of an educator at a university in Zimbabwe is a masters' degree. Years of work experience were almost evenly distributed. The distribution was as follows; 6 (19\%) for less than 3 years, 5 (16\%) for 3-6 years, 7 (23\%) for 7-10 years, $4(13 \%)$ for $11-15$ years, 4 (13\%) for $16-24$ years and 5 (16\%) for 25 years and above. The university had three faculties and their representation was as follows; faculty of Agribusiness \& Entrepreneurship 11 (41\%), Earth and Environmental sciences 7 (26\%) and Agricultural Sciences and Technology 9 (33\%). This shows that there was a fair faculty representation in this study. Distribution based on departments were as follows; Supply chain management 4 (15\%), Development sciences 7 (26\%), Environmental sciences and technology 3 (11\%), Natural resources management 4 (15\%), Horticulture 2 (7\%), Crop science 4 (15\%) and Animal production sciences and health $3(11 \%)$. This shows that there was a fairly balanced departmental representation in this study since all the departments were represented except the Business management department which was excluded from the study in order to maintain objectivity.

\section{Research Question 1:}

What are the perceptions of educators towards the adoption of Education 5.0?

Variable mean score results as perceived by participants are as follows: Attitude towards the adoption of education 5.0 had the mean of 3.68, usefulness had the mean score of 4.04 , physical infrastructure had the mean score of 2.03, financial resources had the mean score of 2.31, relative advantage had the mean score of 3.92 while simplicity had the mean score of 3.10 . Therefore, it can be interpreted that the educators' attitude towards the adoption of Education 5.0 and their perceived usefulness of the reform was positive meaning that they viewed the change to be necessary and useful. This could be because some of these educators were youthful and studies show that young people are generally pro to change than old ones (Paul, \& Stegbauer, 2005). Education 5.0 has an element of innovation which the young people are more interested in than the aged ones. Physical infrastructure and financial resources were rated negatively on the institution's readiness for the adoption of Education 5.0. The absence of adequate physical infrastructure and financial resources to support Education 5.0 adoption is expected since Zimbabwe as a nation is undergoing an economic meltdown. Capital investments need huge financial resources which could not be availed with limited resources available.

The educators, however, viewed Education 5.0 adoption to be of relative advantage although there were neutral responses on its simplicity. Since Education 5.0 is a new curriculum reform which is at its implementation stage, it is understandable that educators were not sure if Education 5.0 was simple to implement or not. New programs come with their different conditions that might be also new to the implementers such that making a judgement on the program's complexity or simplicity would need some time for the users to interact with it.

Responses further revealed that there was no adequate physical infrastructure and financial resources to support Education 5.0. With the increase in number of state tertiary education institutions which are currently at eighteen (10 state universities and 8 poly-technic colleges), it is expected that state funding on university infrastructure is not adequate. Educators perceived that Education 5.0 had relative advantages over Education 3.0.

\section{Research Question 2:}

What is the level of readiness for Education 5.0 adoption among educators?

Individual factors had a mean of 3.86 which showed that respondents were somewhat ready for Education 5.0 adoption. Since all of the university educators under this study are academically qualified for their jobs (masters and doctorate degrees) and a good number of them are young, this factor could explain why they are somewhat ready for Education 5.0 adoption. This is supported by Bandura (2010) and Schwarzer (2014) who state that self-efficacy leads to high readiness for change adoption because of an individual's belief in their ability. The qualified personnel will have the courage to tackle the challenges that come with a change in curriculum more than the unqualified 
staff. This result is also supported by the Technology Acceptance Model which states that the individual's attitude and their perceived usefulness of the new technology has an effect on its adoption (Davis, 1989).

Availability of resources had a mean of 2.17 which indicates that the university under investigation was somewhat not ready for education 5.0 in terms of resources. The university under discussion had less than five years of existence and hence still in its infancy which under normal circumstances need a lot of resources.

On innovation characteristics, an average of 3.51 showed that the educators somewhat perceived that Education 5.0 was a worthwhile curriculum reform since it had relative advantages over Education 3.0 and was also somewhat simple to implement. The study results further show that educators perceived Education 5.0 as useful and more beneficial to the tertiary education system than the preceding Education 3.0, although they bemoaned lack of infrastructure and financial resources for proper implementation.

\section{Conclusions and Recommendations}

Based on findings of the study, this section gives the conclusion and recommendations of the study.

\section{Conclusions of the Study}

The study concludes that the university educators generally had a positive attitude towards the adoption of Education 5.0, perceived it to be useful and of relative advantage than the preceding Education 3.0.

Secondly, the educators were somewhat ready for Education 5.0 adoption yet the university was somewhat not ready for the adoption because of limited resources.

\section{Recommendations of the Study}

The following recommendations were based on the results of the study: The researchers recommend that seminars on Education 5.0 be done to lecturers since they are directly involved in its implementation so as to improve their readiness for Education 5.0 adoption.

Secondly, the university should approach business partners and banks to mobilize financial resources and to build physical infrastructures such as industrial parks to support Education 5.0.

\section{Reference}

Aarons, G. A., Hurlburt, M., \& Horwitz, S. M. (2011). Advancing a conceptual model of evidencebased practice implementation in public service sectors. Administration and Policy in Mental Health and Mental Health Services Research, 38(1), 4-23. doi: 10.1007/s10488010-0327-7

Armenakis, A. A., Harris, S. G., \& Mossholder, K. W. (1993). Creating readiness for Organizational change. Human Relations, 46(3), 681-703. doi: 10.1177/001872679304600601

Armstrong, D. G. (2003). Curriculum today. Upper saddle river, New Jersey: Pearson education

Bandura, A. (2010). Self-efficacy. The Corsini encyclopedia of psychology, 1-3.

Blazar, D. \& Kraft, M. A. (2017). Teacher and teaching effects on students' attitudes and behaviors. Educational evaluation and policy analysis.ncbi.nlm.nih.gov.

Davis, F. D. (1989). Perceived usefulness, perceived ease of use, and user acceptance of information technology. MIS Quarterly, 13(3), 319-340. Retrieved from https://pdfs.semanticscholar.org/3969/e58 2e68e418a2b79c604cd35d5d81de9b35d.pd $f$

Gordon, R. (1994). Education policy and gender in Zimbabwe. Gender and Education, 6(2), 131139.

Harpe, B. D. L., \& Thomas, I. (2009). Curriculum change in universities: Conditions that facilitate education for sustainable development. Journal of Education for Sustainable Development, 3(1), 75-85. Retrieved from https://journals.sagepub.com /doi/pdf/10.1177/097340820900300115

Hayes, J. (2010). The Theory and Practice of Change Management (3rd ed.). England, UK: Palgrave Macmillan.

Jabri, M. (2012).Managing organizational change: Process, social construction and dialogue. New York, NY: Palgrave Macmillan.

Jones, S., Sutcliffe, M. J., Bragg, J. \& Harris, D. (2016). To what extent is capital expenditure in UK higher education meeting the pedagogical needs of staff and 
students?, Journal of Higher Education Policy and Management, 38(4), 477-489, DOI: $10.1080 / 1360080 X .2016 .1181881$

Kadenge, M \& Nkomo, D. (2011). The politics of the English language in Zimbabwe, Language Matters, 42:2, 248-

263, DOI: $10.1080 / 10228195.2011 .581679$

Kanyongo, G. Y., (2005). Zimbabwe's public education system reforms: successes and challenges. International Education Journal, 6 (1), 65-74.

Karp, M. M., \& Fletcher, J. (2014). Adopting new technologies for student success: $A$ readiness framework. Community College Research Center. Columbia University. Retrieved from http://ccrc.tc.columbia.edu/media/k2/attac hments /adopting-new-technologies-forstudent-success.pdf

Kotter, J. P. (1995). Leading change: Why transformation efforts fail. Harvard Business Review. Retrieved from https://cb.hbsp.harvard.edu/resources/mar keting /docs/95204f2.pdf

Kotler, P., \& Armstrong, G. (2012). Principles of Marketing $\left(13^{\text {th }}\right.$ ed.). Upper saddle river, New Jersey: Pearson education

Kotler, P. (2012). Kotler on marketing. Simon and Schuster.

Mack, L. (2010). The Philosophical Underpinnings of Educational Research. Retrieved frohttp://www.apu.ac.jp/rcaps/uploads/fck editor/publications/polyglossia/Polyglossia_ V1 9_Lindsay.pdf

Mapara, J. (2009). Indigenous knowledge systems in Zimbabwe: Juxtaposing postcolonial theory. Journal of Pan African Studies, 3(1).

Ministry of Higher and Tertiary Education, Science and Technology Development. (2018a). Doctrine for the Modernisation and Industrialisation of Zimbabwe through Education, Science and Technology Development to achieve Vision 2030: Government Gazette.

Ministry of Higher and Tertiary Education, Science and Technology Development. (2018b). Biotechnology and Advanced Cattle Reproductive Technologies. Government Gazette.

Ministry of Higher and Tertiary Education, Science and Technology Development. (2018c). Study in Zimbabwe: Towards vision 2030. Government Gazette.
Murwira, A. (2019). Towards revitalising the roles of Universities in development [Zimbabwe] Retrieved from https://www.ruforum.org/AGM2019/sites /default/files/HON_MINISTER_PROF_MUR WIRA_SPEECH.pdf

Muzira, D. R., 2018, 'Factors affecting readiness for integrated reporting adoption: A study of Zimbabwean companies', PhD. Dissertation, Adventist International Institute of Advanced Studies.

Naqvi, R., Malik, F. A. R. Y. A. L., \& Mahmood, Q. U. R. R. A. T. U. L. A. I. N. (2013). The impact of promotions, recognition and autonomy and pay incentives on job satisfaction: A case of banking sector employees in Pakistan. European Journal of Business Management, 5(5), 187-193.

Needham, D. E. (1974). Iron age to independence: $a$ history of Central Africa. Longman Publishing Group.

Nyota, S. and J. Mapara. 2008. Shona Traditional children's games and play songs as indigenous ways of knowing, in I.M. Zulu (ed.), Journal of Pan African Studies, 2(4), pp 184-202. Online: http://www.jpanafrican.com

Ornstein, A. C., \& Hunkins, F. P. (2013). Curriculum: Foundations, Principles, and Issues. Upper saddle river, New Jersey: Pearson education

Paul, G., \& Stegbauer, C. (2005). Is the digital divide between young and elderly people increasing?. First Monday, 10(10).

Rogers, E.M., \& Shoemaker, F. F. (1971). Communication of innovation: A crosscultural Approach, (2nd ed.). New York, NY: The Free Press.

Rogers, E. M. (2003). Diffusion of Innovations (5ted.). New York, NY: Free.

Sarup, M. (2013). Marxism and Education (RLE Edu L): A Study of Phenomenological and Marxist Approaches to Education. Routledge.

Saunders, M., Lewis, P., \& Thornhill, A. (2008). Research methods for business students (5th ed.). London, UK: Pearson Education.

Schwarzer, R. (2014). Self-efficacy: Thought control of action. Taylor \& Francis.

Shizha, E., \& Kariwo, M. T. (2011). Education and Development in Zimbabwe: A social, political and economic analysis. Boston, Sense publishers

Solomons, N. M., \& Spross, J. A. (2011). Evidencebased practice barriers and facilitators from 
a continuous quality improvement perspective: An integrative review. Journal of Nursing Management, 19(1), 109-120. Retrieved from http://onlinelibrary.wiley.com/doi/10.1111/ j.1365-2834.2010.01144.x/pdf

Tirivangana, A. (2019). Education 5.0 and Vision 2030, re-configuring Zim university degrees. The Patriotic, March 28, 2019. Retrieved from https://www.thepatriot.co.zw /education/education-5-0-and-vision-2030re-configuring-zim-university-degrees/

Vroom, V. H. (1964). Work and motivation. Retrieved https://books.google.com.ph/books/about/ Work_and_Motivation.ht ml?id=bq_QgAACAAJ\&redir_esc=y

Woiceshyn, J., Daellenbach, U. (2018). Evaluating inductive vs deductive research in management studies: Implications for authors, editors, and reviewers. Qualitative Research in Organizations and Management: An International Journal, 13(2),183-195, https://doi.org/10.1108/QROM-06-20171538

Zvobgo, R. J. (1986). Transforming Education: The Zimbabwean experience. College Press. 